\title{
Research on the Development of China's Logistics
}

\author{
Junye Zhang1*, Yali Dong2, Wei Huang ${ }^{3}$, De Chen ${ }^{4}$ \\ ${ }^{1}$ School of Logistics, Beijing Wuzi University, Beijing, China \\ ${ }^{2}$ Sleemon North Furniture Co., Ltd., Langfang, China \\ ${ }^{3}$ School of Logistics, Shanghai Maritime University, Shanghai, China \\ ${ }^{4}$ Law School, Peking University, Beijing, China \\ Email: *7935822@qq.com
}

How to cite this paper: Zhang, J.Y., Dong, Y.L., Huang, W. and Chen, D. (2019) Research on the Development of China's Logistics. Open Journal of Business and Management, 7, 400-426.

https://doi.org/10.4236/ojbm.2019.72028

Received: January 18, 2019

Accepted: February 24, 2019

Published: February 27, 2019

Copyright (C) 2019 by author(s) and Scientific Research Publishing Inc. This work is licensed under the Creative Commons Attribution International License (CC BY 4.0).

http://creativecommons.org/licenses/by/4.0/

\begin{abstract}
The purpose of this paper is to explore the current state of China's logistics development and the future development. In order to fulfill the research objective, a literature-based survey and content analysis is used to investigate the development level of China's logistics research, also, second-hand data based statistical analysis is used as the main method to study the development of Chinese logistics in this paper. While every effort has been made to ensure that the most up-to-date data is available in the analysis, this is not always possible due to the obvious reasons for data scarcity and data integrity. Despite the improvements and progress made by the government and other agencies, the current logistics infrastructure, especially the transportation network, customs procedures and warehousing facilities are still lacking. Future developments are also highlighted to portray an accurate assessment of China's logistics situation. This is the latest comprehensive research on the development of China's logistics in the known scope. It provides an opportunity for companies that want to enter the Chinese market to understand the development of China's logistics.
\end{abstract}

\section{Keywords}

China, Logistics, Development, Reform and Opening, Transportation, Customs, Warehousing

\section{Introduction}

China's per capita GDP has remained almost unchanged over the past millennium. Since 1978, GDP has risen almost vertically, and China's total economic 
output has since entered an annual growth rate of nearly 10\% [1]. In 1978, China began the reform and opening. This huge market was exposed to the world. In 2001, China's accession to the WTO marked a new stage for China's opening. Since 2011, China has become the second largest economy in the world and has entered the middle and upper income countries. The convening of the $18^{\text {th }} \mathrm{Na}$ tional Congress of the Communist Party of China in 2012 marked China's entry into a comprehensive well-off society. The logistics industry, as a composite service industry integrating the transportation, telecommunications, customs and warehousing, is an important part of the national economy. It plays an important role in promoting industrial restructuring, transforming economic development methods and enhancing national economic competitiveness.

Since the reform and opening, China's logistics has developed rapidly. Some scholars have noticed this. Jiang and Prater noticed that China's logistics industry is undergoing a revolution from a planned economy to a market economy [2]. Goh and Ling compared the changes in logistics before and after China's accession to the WTO and that entering the WTO has promoted the development of China's logistics industry [3]. Hong and Liu studied the development of China's logistics from the perspective of suppliers and made suggestions for logistics managers and policy makers [4]. A review of China-based literatures conducted to investigate the extent to which research opportunities on China's logistics [5]. Some scholars also made comprehensive reviews of China's logistics development to a certain degree this year. Ding made a summary of the development of the logistics industry since the founding of New China and revealed the process of the evolution of China's logistics industry from traditional to modernization [6]. Wang and He summarized the stage characteristics of China's logistics development and focused on the nation's policies on logistics [7].

At the time of the $40^{\text {th }}$ anniversary of China's reform and opening, it is necessary to have a timely and comprehensive research on assessing China's logistics current status in transportation, customs and warehousing. Understanding the infrastructural conditions, limitations and future developments will enable government, multinational companies and LSPs to develop better appropriate strategies to logistical challenges. We rely primarily on archival data obtained from reliable sources, such as the National Bureau of Statistics of China and the National Statistical Yearbook, to provide most of the statistical information. Although every effort has been made to ensure that the most up-to-date data is available in the analysis, this is not always possible due to the obvious reasons for data scarcity and data integrity.

The rest of this article is organized as follows. Section 2 describes current developments, constraints and challenges, and the future development of various major modes of transportation. Sections 3 and 4 illustrate the current developments, constraints and challenges of customs management and warehousing, as well as future developments. Section 5 provides some concluding observations. 


\section{Transportation}

\subsection{Highway Transport}

\subsubsection{Current Developments}

Since the mid-1970s, especially 1978, the freight volume on highways (including expressways) has increased year-on-year (Figure 1). In 2017, the volume of goods transported was 36.8 billion tons, a year-on-year increase of $10.1 \%$ [8]. In fact, highways have always been the main mode of transportation, increasing from $48 \%$ to $77 \%$ of the total freight moved between 1978 and 2017. In 2017, Guangdong, Shandong, Anhui, Henan, Hebei had the highest volumes of freight transported via highways [9].

The increase in road freight volume is not surprising, for a long time, road/ highway mileage has been ranked first in the length of different modes of transport, until it was surpassed in recent years, but still has a high proportion (Figure 2). From 2016 to 2017 alone, the length of highways increased by 78,200 km and the total length of the highway reached 4.8 million $\mathrm{km}$. According to statistics,

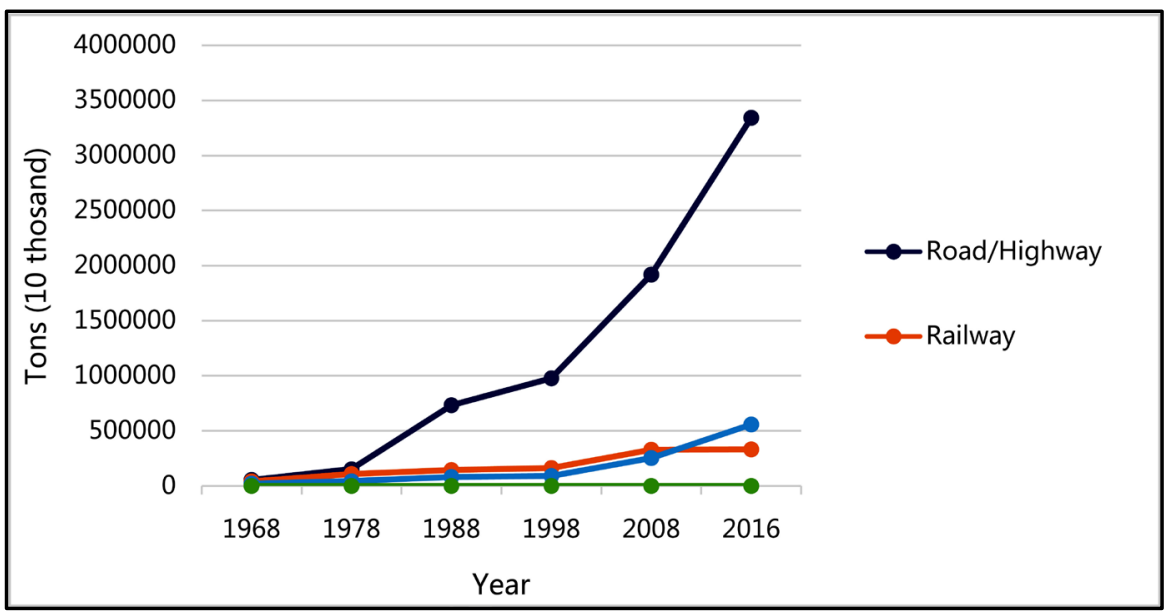

Source: National Bureau of Statistics of China (2018).

Figure 1. Freight volume (1968-2016).

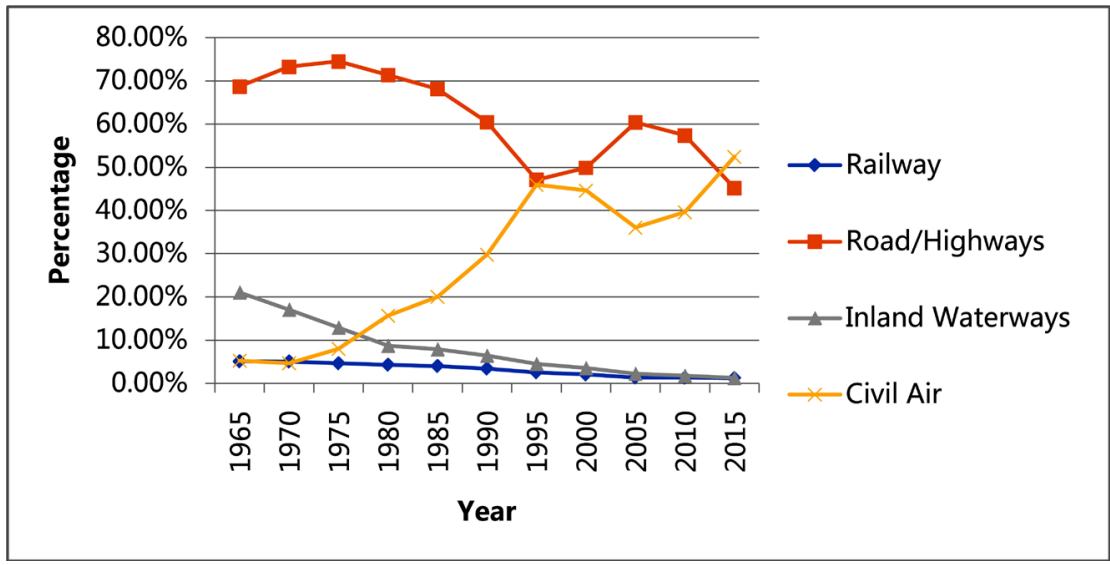

Source: National Bureau of Statistics of China (2018).

Figure 2. Length of transport routes (1965-2015). 
there are as many as 12 provinces with a mileage of over $5000 \mathrm{~km}$ at the end of the "12 $2^{\text {th }}$ Five-Year Plan" (2011-2015), of which Guangdong Province ranks first with $7018 \mathrm{~km}$, Hebei Province with second place with $6333 \mathrm{~km}$, and Henan Province ranks third [10]. In 2012, China's expressway mileage reached 96,000 km, surpassing the United States' 92,000 km, ranking first in the world. In 2017, China's highway mileage increased to 131,000 kilometers, keeping ranking first in the world, nearly $30,000 \mathrm{~km}$ more than the US highway mileage.

Most of the goods transported by highway are short-haul because the average distance traveled by each road is about $183 \mathrm{~km}$, while the average length of rail freight is about $714 \mathrm{~km}$ (National Bureau of Statistics of China, 2018). Therefore, for a long time, compared with inland waterways and railways, highways registered freight ton-km is relatively low (Figure 3 ). Thanks to the rapid growth in highway mileage and number of trucks (Table 1), road freight turnover grew rapidly in 2005 and later exceeded rail freight turnover.

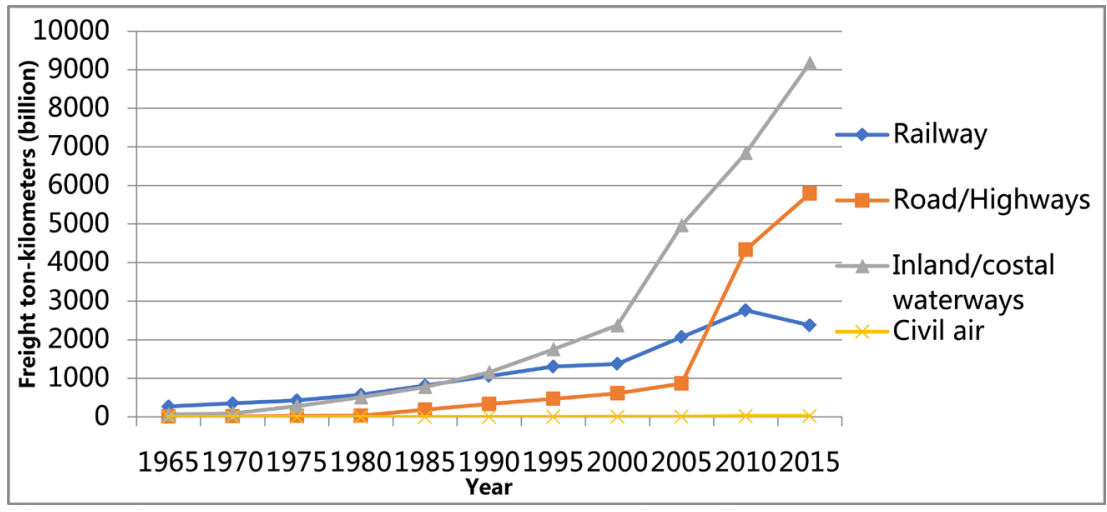

Source: National Bureau of Statistics of China (2018).

Figure 3. Freight ton-kms (1965-2015).

Table 1. Highway vs railway in length and number of freight vehicles.

\begin{tabular}{ccccc}
\hline \multirow{2}{*}{ Year } & \multicolumn{2}{c}{ Length (million $\mathrm{km}$ ) } & \multicolumn{2}{c}{ Number of freight vehicles (million) } \\
\cline { 2 - 5 } & Highway & Railway & Highway & Railway \\
\hline 2005 & 3.35 & 0.075 & 4.52 & 0.54 \\
2006 & 3.46 & 0.077 & 4.94 & 0.56 \\
2007 & 3.58 & 0.078 & 5.39 & 0.58 \\
2008 & 3.73 & 0.080 & 5.96 & 0.59 \\
2009 & 3.86 & 0.086 & 7.53 & 0.60 \\
2010 & 4.01 & 0.091 & 9.31 & 0.62 \\
2011 & 4.11 & 0.093 & 10.67 & 0.65 \\
2012 & 4.24 & 0.098 & 11.76 & 0.67 \\
2013 & 4.36 & 0.103 & 12.75 & 0.72 \\
2014 & 4.46 & 0.112 & 13.53 & 0.72 \\
2015 & 4.58 & 0.121 & 13.31 & 0.77 \\
\hline
\end{tabular}




\subsubsection{Constrains and Challenges}

Although the length of the highway increases, the rate of increase in the length of the highway is usually much slower than the increase in the freight volume (Table 2). Therefore, it is common to illegally modify vehicles to increase their capacity. In addition, with the continuous efforts to restore and maintain these highways, road engineering will inevitably cause bottlenecks and hinder traffic flow. In terms of regulation, the Government is also increasing the number of road inspections to prevent vehicles from overloading their statutory restrictions. However, the effectiveness of these inspections is affected by the unwillingness of transportation companies to cooperate. Another problem relates to vehicles for shipping, which are typically convertibles that are only covered by tarpaulins. While the use of these vehicles may result in cost savings, the cost due to loss and damage to the cargo is significant and common. There are also cases where people and goods are mixed and easily cause casualties.

\subsubsection{Future Developments}

The Government will continue to invest heavily in highway development. By 2020 , an additional 1 million $\mathrm{km}$ of highway will be completed, bringing the total length of the highway to 5 million $\mathrm{km}$, an increase of about $6 \%$ per year [11]. During the " $13^{\text {th }}$ Five-Year Plan" period (2016-2020), the National Trunk Highway System (NTHS) which is known as "7918 Highway Net" will continue to be built, which is a project supported by the World Bank. The System has been in construction since 1984 and will be completed in 2030. Upon completion, the 118,000-km NTHS will have 36 inter-provincial highways connecting hundreds of cities. The System consists of 7 capital (Beijing) radiation highways, 11 north-south vertical highways and 18 east-west horizontal highways (Table 3).

The Chinese government is also constantly building other highways that are not part of the NTHS. These include the Tongjiang (Heilongjiang)-Sanya (Hainan) Highway, Heihe (Heilongjiang)-Hong Kong, Macau Highway and Shanghai-

Table 2. Highway freight volume vs length (1965-2015).

\begin{tabular}{cccc}
\hline Year & $\begin{array}{c}\text { Freight volume } \\
\text { (million tons) }\end{array}$ & $\begin{array}{c}\text { Length } \\
\text { (million km) }\end{array}$ & $\begin{array}{c}\text { Freight volume/length } \\
\text { (ton/km) }\end{array}$ \\
\hline 1975 & 1176.33 & 0.7836 & 1501.19 \\
1980 & 1421.95 & 0.8883 & 1600.75 \\
1985 & 5380.62 & 0.9424 & 5709.49 \\
1990 & 7240.40 & 1.0283 & 7041.14 \\
1995 & 9403.87 & 1.1570 & 8127.80 \\
2000 & $10,388.13$ & 1.6798 & 6184.15 \\
2005 & $13,417.78$ & 3.3452 & 4011.05 \\
2010 & $24,480.52$ & 4.0082 & 6107.61 \\
2015 & $31,500.19$ & 4.5773 & 6881.83 \\
\hline
\end{tabular}

Source: National Bureau of Statistics of China (2018). 
Table 3. Inter-provincial highways of the NTHS.

\begin{tabular}{|c|c|}
\hline Highway & Length $(\mathrm{km})$ \\
\hline \multicolumn{2}{|l|}{ Capital radiation highways } \\
\hline Beijing-Harbin (Heilongjiang) & 1209 \\
\hline Beijing-Shanghai & 1262 \\
\hline Beijing-Taipei (Taiwan) & 2030 \\
\hline Beijing-Hong Kong, Macau & 2285 \\
\hline Beijing-Kunming (Yunnan) & 2865 \\
\hline Beijing-Lhasa (Tibet) & 3710 \\
\hline Beijing-Urumqi (Xinjiang) & 2540 \\
\hline \multicolumn{2}{|l|}{ Vertical highways } \\
\hline Hegang (Heilongjiang)-Dalian (Liaoning) & 1485 \\
\hline Shenyang (Liaoning)-Haikou (Hainan) & 3710 \\
\hline Changchun (Jilin)-Shenzhen (Guangdong) & 3585 \\
\hline Jinan (Shandong)-Guangzhou (Guangdong) & 1947 \\
\hline Daqing (Heilongjiang)-Guangzhou (Guangdong) & 3550 \\
\hline Erenhot (Inner Mongolia)-Guangzhou (Guangdong) & 2685 \\
\hline Baotou (Inner Mongolia)-Maoming (Guangdong) & 3130 \\
\hline Yan'an (Shaanxi)-Xi'an (Shaanxi) & 320 \\
\hline Hohhot (Inner Mongolia)-Beihai (Guangxi) & 2628 \\
\hline Yinchuan (Ningxia)-Baise (Guangxi) & 2281 \\
\hline Lanzhou (Gansu)-Haikou (Hainan) & 2650 \\
\hline Yinchuan (Ningxia)-Kunming (Yunnan) & 2322 \\
\hline \multicolumn{2}{|l|}{ Horizontal highways } \\
\hline Suifenghe(Heilongjiang)-Manzhouli (Inner Mongolia) & 1527 \\
\hline Hunchun (Jilin)-Ulanhot (Inner Mongolia) & 925 \\
\hline Dandong (Liaoning)-Xilinhot (Inner Mongolia) & 960 \\
\hline Rongcheng (Shandong)-Wuhai (Inner Mongolia) & 1820 \\
\hline Qingdao (Shandong)-Yinchuan (Ningxia) & 1610 \\
\hline Qingdao (Shandong)-Lanzhou (Gansu) & 1795 \\
\hline Lianyungang(Jiangsu)-Khorgos(Xinjiang) & 4395 \\
\hline Nanjing (Jiangsu)-Luoyang (Henan) & 722 \\
\hline Shanghai-Xi'an (Shaanxi) & 1490 \\
\hline Shanghai-Chengdu (Sichuan) & 1966 \\
\hline Shanghai-Chongqing & 1768 \\
\hline Hangzhou (Zhejiang)-Ruili(Yunnan) & 3404 \\
\hline Shanghai-Kunming (Yunnan) & 2730 \\
\hline Fuzhou (Fujian)-Yinchuan (Ningxia) & 2485 \\
\hline Quanzhou (Fujian)-Nanning (Guangxi) & 1635 \\
\hline Xiamen (Fujian)-Chengdu (Sichuan) & 2295 \\
\hline Shantou (Guangdong)-Kunming (Yunnan) & 1710 \\
\hline Guangzhou (Guangdong)-Kunming (Yunnan) & 1386 \\
\hline
\end{tabular}

Source: National Highway Network Planning (2013-2030). 
Zhangmu (Tibet) Highway. In 2020, China will build a "Ten Vertical and Ten Horizontal" comprehensive transportation channel that traverses east and west, runs through the north and south, and is open to the outside world. The edge channel around China's land will also be established [11]. Highway standards will also be upgraded. As for Western China, the Government will use Xinjiang as the core area to build land bridges and transportation corridors, laying the foundation for building the "Belt and Road". In the whole of China, the highway will develop from a linear operation to a "one highway network".

\subsection{Rail Transport}

China's railways are divided into national, local and joint ventures (JV, between national and local) railways. Unless otherwise stated, this section will collectively refer to these three types of railways.

\subsubsection{Current Developments}

Railways are broadly divided into East-West and North-South lines. At present, China's railways have formed a "three horizontal (east-west) lines and five vertical (north-south) lines" pattern. Three horizontal lines are Beijing-Baotou-Lanzhou line, Lianyungang-Lanzhou-Alashankou (Xinjiang) line and Shanghai-Kunming line. The vertical lines connect Beijing with Shanghai, Beijing with Kowloon, Beijing with Guangzhou as well as Taiyuan with Liuzhou (Guangxi) and Baoji (Shaanxi) with Kunming.

Rail transport has been growing steadily since the 1960s and has been the second most popular mode of transport for more than 40 years (Figure 1). In 2016, the volume of goods transported by rail reached 3332 million tons, while the freight turnover reached 2,379,226 million ton-kilometers (National Bureau of Statistics of China, 2018). In terms of freight turnover, the railway was more popular than the highway from the 1960 s to the first decade of the $21^{\text {st }}$ century, because the railway was used for further delivery, though not more than the highway. The increase in freight volume is mainly from heavy and bulky goods such as coal, steel and iron. Shanxi, Heilongjiang, Liaoning, Hebei, Shandong, Henan and other regions are rich in such resources, so the freight volume of railway has been very large. For instance, in 2016, they registered 1378 million tons of freight moved by railway (National Bureau of Statistics of China, 2018). Correspondingly, the use of containers on trains also showed good growth in 2016, handling 7.61 million TEUs [12]. According to the Ministry of Transport, this usage is expected to increase.

Although the freight volume increased by 26 times from 1975 to 2015, the total length of the railway only increased by 5 times (Table 2). During the same period, the length of the electrified national railway track and the dual-track national railway increased by 21 times and 3 times respectively, which was impressive (Table 4). At present, the transportation mileage of China's railways and electrified railways has reached the second place in the world [13].

In 2014, with the rise of China Railway Express (China-Europe block train 
ferry), it has become an important part of the "Belt and Road" strategy. China Railway Express (CR Express) is the China-Europe block train ferry, which is organized by the China Railway Corporation, operated in the international railway container intermodal transportation mode in China-Europe along the "Belt and Road".

The CR Express corridors are divided into West, Middle, East and South corridors (Table 5).

From 2011 to 2017, average annual growth rate attained to 44\%, the cumulative CR Express trains were 6637. The total number of trains in 2017 exceeded the total of 2011 to 2016 (Figure 4). By the end of June 2018, the cumulative number of CR Express trains had exceeded 9000, with nearly 800,000 TEUs of

Table 4. Railway infrastructure developments.

\begin{tabular}{|c|c|c|c|c|c|c|c|c|}
\hline & 1980 & 1985 & 1990 & 1995 & 2000 & 2005 & 2010 & 2014 \\
\hline Length of railways in operation $(\mathrm{km})$ & 53,300 & 55,200 & 57,900 & 62,400 & 68,700 & 75,400 & 91,200 & 111,800 \\
\hline Length of electrified national railways $(\mathrm{km})$ & 1700 & 4100 & 6900 & 9700 & 14,900 & 19,400 & 32,700 & 36,900 \\
\hline $\begin{array}{l}\text { As percent of length of national railways in operation } \\
\text { (per cent) }\end{array}$ & 3.41 & 7.87 & 12.92 & 17.77 & 25.38 & 31.19 & 49.4 & 55.07 \\
\hline Length of national railways with double-tracks $(\mathrm{km})$ & 8100 & 10,000 & 13,000 & 16,900 & 21,400 & 24,500 & 29,700 & 32,500 \\
\hline $\begin{array}{l}\text { As percent of length of national railways in operation } \\
\text { (per cent) }\end{array}$ & 16.23 & 19.19 & 24.34 & 30.95 & 36.46 & 39.39 & 44.86 & 48.51 \\
\hline
\end{tabular}

Source: National Bureau of Statistics of China (2018); Note: Some of the data was last updated to 2014, so the 2014 data was selected as the latest data.

Table 5. CRE corridors.

\begin{tabular}{ll}
\hline CR Express corridors & Brief description \\
\hline West corridor & I: Leave the border at Alataw (Khorgos) port, through Kazakhstan then connected to Siberia railway of Russia, the route \\
through Belarus, Poland, Germany, and then access to other European countries. \\
II: Leave the border at Khorgos (Alataw) port, through Kazakhstan, Turkmenistan, Iran, Turkey and other countries, \\
access to European countries; or through Kazakhstan across the Caspian Sea, entering Azerbaijan, Georgia, Bulgaria and \\
other countries, access to European countries. \\
III: Leave the border at Turgart (lrkeshtam), connecting China-Kyrgyzstan-Uzbekistan Railway (in planning), through \\
Kyrgyzstan, Uzbekistan, Iran, Turkmenistan, Turkey and other countries, access to European countries. \\
Leave the border at Erenhot port, through Mongolia, connected with Siberia railway of Russia, access to European \\
countries. \\
Leave the border at Manchuria port in Inner Mongolia, connected with Siberia railway of Russia, access to European \\
countries. \\
I: Leave the border at the Khunjerab port, through lslamabad to Gwadar Port (the China-Pakistan Corridor), total mileage \\
is about 6280 km. \\
II: Leave the border at Ruili port, through the port of Kyaukpyu-Chittagong(-Yangon)-Calcutta, after a total of 4 countries \\
(BCIM corridor), total mileage is about 3510 km. \\
III: Leave the border at Mohan port, through the Vientiane-Bangkok-Kuala Lumpur-Singapore (Indochina Peninsula \\
corridor), after a total of 5 countries, the total mileage of about 3910 km.
\end{tabular}




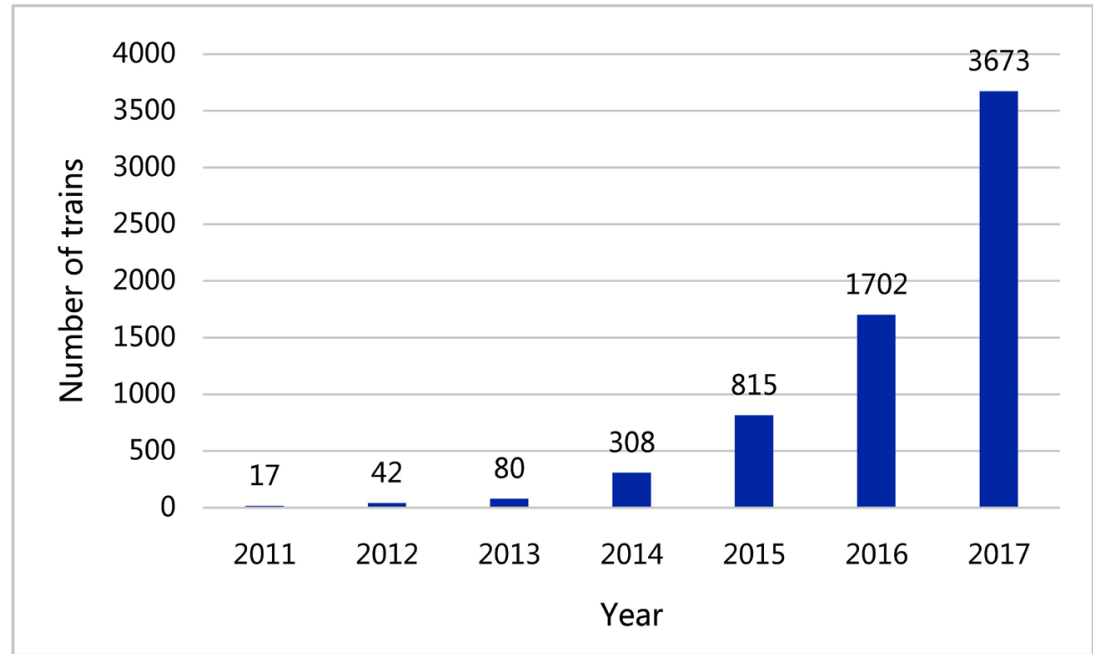

Source: China Railway Container Transport Co., Ltd.

Figure 4. Development of number of trains of CRE.

goods, 48 domestically operated cities, and 42 cities in 14 countries in Europe. The transportation network covers the major areas of Asia and Europe [14]. On August 26, 2018, the number of CRE trains reached 10,000 [15].

\subsubsection{Constrain and Challenges}

From 2009 to 2014, national railways, operating at almost full capacity (over 97\%) (National Bureau of Statistics of China, 2018), were unable to meet additional demand. According to the Ministry of Transport, more than $50 \%$ of freight must seek other means of transportation [16] such as highways. The capacity shortage in the northeastern region where the heavy industry base is located is particularly serious. Given the priority of railways to transfer industrial resources such as coal and steel, commodities face greater difficulties in obtaining rail space. Due to this shortage of capacity, the departing train is usually fully loaded. This results in uncertain starting and arrival times, so it is very time consuming to distribute by rail. Trains that crawl at an average speed of 35.6 $\mathrm{km} / \mathrm{h}$ (National Bureau of Statistics of China, 2018) further exacerbate this situation.

\subsubsection{Future Developments}

In the $13^{\text {th }}$ Five-Year Plan, the Government plans to allocate RMB 3.5 trillion to build new railways, improve existing networks and increase delivery speed. During this period, an additional $30,000 \mathrm{~km}$ of new railways will be built to bring the total length of the railway to $150,000 \mathrm{~km}$, with double-tracks railways rate and electrified railways rate reaching $60 \%$ and $70 \%$ respectively. A major project undertaken is to continue to expand the scale of the road network in the central and western regions, reaching $90,000 \mathrm{~km}$ by the end of the $13^{\text {th }}$ Five-Year Plan [17].

There are also plans to link China to the rest of the world by rail. For instance, the high-speed rail connecting Kunming and Singapore, which started in 2011, 
will open to traffic in 2020. A similar construction is being carried out for the Eurasian Continental Bridge, linking China to Serbia.

As containers become more popular, another goal of Ministry of Transport is to improve container handling facilities and introduce containerized tracking systems. Refrigerated containers for perishable goods and special containers for gas and liquids will also be purchased. This should lead to more service choices and smoother multimodal transport.

The World Bank approved a USD 300 million loan for the construction of the $343-\mathrm{km}$ double-track electrified passenger and freight dual-purpose railway in Harbin to Jiamusi, Heilongjiang Province, as well as the construction of 12 new stations and the upgrading of Jiamusi Station. The project is expected to be completed in 2019. By then, this new line will shorten the passenger and cargo distance from Harbin to Jiamusi by 164 kilometers, from the current $507 \mathrm{~km}$ to $343 \mathrm{~km}$ [18]. In addition, China also invites foreign investment in railway infrastructure development. In 2018, the Chinese railway industry canceled restrictions on foreign investment, including the abolition of the construction of the railway trunk line network and the restrictions on the operation of the Chinese side, and the removal of the railway passenger transport company from the Chinese holdings. In addition to the previously restricted foreign investment access restrictions for rail transit equipment manufacturing, the railway industry has been largely open. This will promote the capital of all parties to enter the railway infrastructure.

\subsection{Water Transport}

Goods transported by water are usually classified into ocean and inland waterways. In this section, the top ten seaports and inland water ports are identified and the facilities available at these ports are described as they are more likely to become potential logistics hubs.

\subsubsection{Current Developments}

\section{1) Ocean transport}

In 2016, the total throughput of all seaports was 8,109.33 million tons (National Bureau of Statistics of China, 2018). From 2016 to 2017, container throughput in some major ports increased by $1.61 \%$ to $25.8 \%$ (Table 6). In 2017 , in the top 20 container throughput of global ports, there are eight major container ports in mainland China, namely Shanghai Port $\left(1^{\text {st }}\right)$, Shenzhen Port $\left(3^{\text {rd }}\right)$, Ningbo-Zhoushan Port $\left(4^{\text {th }}\right)$, and Guangzhou Port $\left(7^{\text {th }}\right)$, Qingdao Port $\left(8^{\text {th }}\right)$, Tianjin Port $\left(10^{\text {th }}\right)$, Xiamen Port $\left(14^{\text {th }}\right)$ and Dalian Port $\left(16^{\text {th }}\right)[19]$.

According to the 2017 freight volume, Table 7 lists the top ten seaports. Obviously, Shanghai Port and Ningbo-Zhoushan Port remain the most important ports in terms of containers and freight volume (Table 6 and Table 7). However, the importance of Shanghai Port is declining because its freight volume accounts for only $8 \%$ of total freight volume in 2017 , compared to $19 \%$ in the 1990s (National Bureau of Statistics of China, 2018). This decline is attributed to 
Table 6. Container throughput at major ports.

\begin{tabular}{cccc}
\hline Port & TEUs in 2017 (million) & TEUs in 2016 (million) & Per cent change (per cent) \\
\hline Shanghai & 40.30 & 37.13 & 8.54 \\
Shenzhen & 26.00 & 24.22 & 7.35 \\
Ningbo-Zhoushan & 25.97 & 21.57 & 20.40 \\
Guangzhou & 20.30 & 18.58 & 9.26 \\
Qingdao & 18.30 & 18.01 & 1.61 \\
Tianjin & 15.20 & 14.50 & 4.83 \\
Xiamen & 10.30 & 9.60 & 7.29 \\
Dalian & 9.90 & 9.59 & 3.23 \\
Yingkou & 6.20 & 6.01 & 3.16 \\
Suzhou (inland water) & 5.90 & 4.69 & 25.80 \\
\hline
\end{tabular}

Source: Wikipedia (2018).

Table 7. Top 10 seaports (2017).

\begin{tabular}{cccc}
\hline Seaports & Administrative region & $\begin{array}{c}\text { Freight volume } \\
\text { (million tons) }\end{array}$ & $\begin{array}{c}\text { Per cent of total freight } \\
\text { volume (per cent) }\end{array}$ \\
\hline Ningbo-Zhoushan & Zhejiang province & 1,007 & 11.68 \\
Shanghai & Shanghai municipality & 706 & 8.19 \\
Guangzhou & Guangdong province & 566 & 6.56 \\
Tangshan & Hebei province & 565 & 6.55 \\
Qingdao & Shandong province & 508 & 5.89 \\
Tianjin & Tianjin municipality & 503 & 5.83 \\
Dalian & Liaoning province & 451 & 5.23 \\
Yingkou & Liaoning province & 362 & 4.20 \\
Rizhao & Shandong province & 360 & 4.17 \\
Yantai & Shandong province & 286 & 3.32 \\
Top 10 seaports & & 5314 & 61.61 \\
All seaports & & 8,625 & 100 \\
\hline
\end{tabular}

Source: Ministry of Transport of China (2018).

the rise of ports such as Ningbo-Zhoushan Port. An interesting phenomenon is that the number of containers handled by Shenzhen Port is in the forefront of the country and the world, but from the perspective of freight volume, the amount of Shenzhen Port is very small. This is because the goods handled by Shenzhen Port is mostly composed of low-density light industrial products such as toys, accessories and clothing.

Figure 5 shows the relationship between the number of berths and freight volume in the top ten seaports.

There seems to be a positive correlation between the two entities because all ports belong to Quadrants II and III. A close inspection revealed that compared 


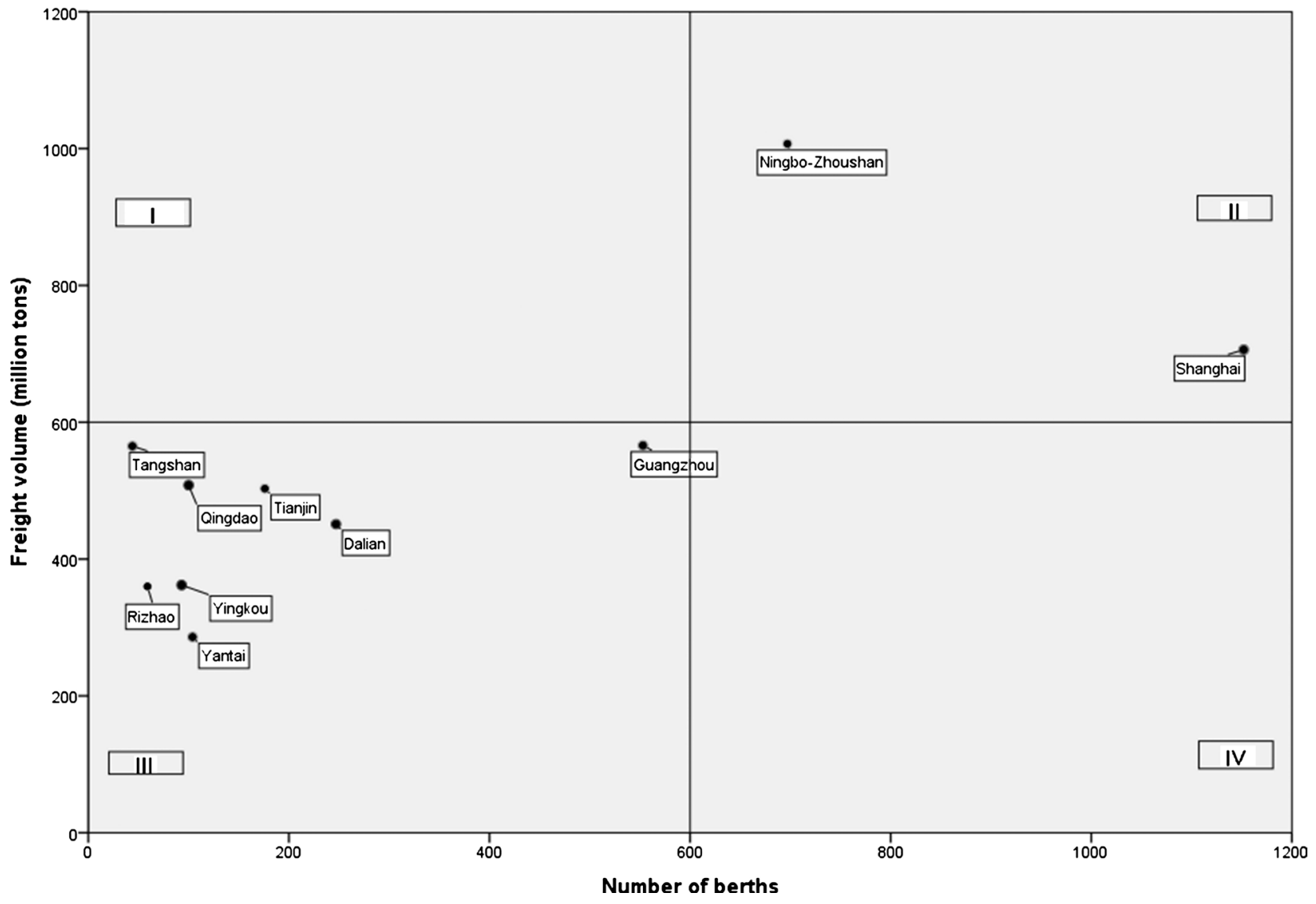

Source: Ministry of Transport of China (2018), National Bureau of Statistics of China (2018).

Figure 5. Productivity of top 10 seaports.

with Yantai and Yingkou Ports, the number of berths in Qingdao Port is almost the same, and its transportation volume is relatively high. Using the freight volume of each berth as a measure of port productivity, Qingdao Port's productivity is relatively high. Accordingly, Tangshan Port is more productive than Guangzhou Port. No port falls in Quadrants I and IV, indicating that the operation of the Chinese seaport is stable. Other aspects of port infrastructure are shown in Table 8.

\section{2) Inland waterway}

The main channels are the Yangtze River, the Pearl River and the BeijingHangzhou Grand Canal. The Yangtze River is the most popular river as it is the longest navigable waterway in the world and can accommodate vessel loads of up to 50,000 tons to Nanjing (Jiangsu), 5000-ton vessels to Wuhan (Hubei) and 1000-ton vessels to Chongqing [20]. The Pearl River connects Guizhou, Guangxi and Guangzhou, and even extends to Hong Kong and Macau. Its main route can handle ship loads of up to 3000 tons [21]. The Beijing-Hangzhou Grand Canal runs through Beijing, Tianjin, Hebei, Jiangsu and Zhejiang. It is the only artificially excavated route in the inland waterway trunk line. It was built in the Spring and Autumn Period (770 BC to 476 BC) with a history of more than 2000 years. After the dredging and extension of different dynasties, the formation of 
today's appearance.

In 2017, the total freight volume of all inland water ports was 4.02 billion tons [22]. According to the freight volume in 2017, China's top ten inland water ports have been identified (Table 9).

Among the top 10 inland water ports, only Hangzhou Port is the port of Qiantang River, but part of it belongs to the Yangtze River Basin. The other nine

Table 8. Port infrastructure of top 10 seaports.

\begin{tabular}{cccc}
\hline Ports & Number berths & $\begin{array}{c}\text { Number of berths for } \\
\text { 10,000-ton ships }\end{array}$ & Length of quays (m) \\
\hline Shanghai & 1152 & 182 & 109,222 \\
Ningbo-Zhoushan & 697 & 163 & 91,029 \\
Guangzhou & 553 & 76 & 54,508 \\
Dalian & 247 & 103 & 44,642 \\
Tianjin & 176 & 121 & 39,389 \\
Yantai & 104 & 65 & 20,624 \\
Qingdao & 100 & 78 & 26,762 \\
Yingkou & 93 & 61 & 19,709 \\
Rizhao & 59 & 52 & 15,440 \\
Tangshan & 44 & 39 & 10,606 \\
Top 10 seaports & 3225 & 940 & 431,931 \\
All seaports & 6069 & 1814 & 827,193 \\
\hline
\end{tabular}

Source: National Bureau of Statistics of China (2018).

Table 9. Top 10 inland water ports (2017).

\begin{tabular}{cccc}
\hline Inland water ports & Administrative region & $\begin{array}{c}\text { Freight volume } \\
\text { (million tons) }\end{array}$ & $\begin{array}{c}\text { Per cent of total freight } \\
\text { volume (per cent) }\end{array}$ \\
\hline Suzhou & Jiangsu province & 608 & 15.13 \\
Nanjing & Jiangsu province & 239 & 5.95 \\
Nantong & Jiangsu province & 236 & 5.87 \\
Taizhou & Jiangsu province & 197 & 4.90 \\
Chongqing & Chongqing municipality & 196 & 4.88 \\
Jiangyin & Jiangsu province & 159 & 3.96 \\
Zhenjiang & Jiangsu province & 144 & 3.58 \\
Wuhu & Anhui province & 128 & 3.18 \\
Yueyang & Hunan province & 121 & 3.01 \\
Hangzhou & Zhejiang province & 108 & 2.69 \\
Top 10 inland water ports & 2,136 & 53.15 \\
\hline
\end{tabular}

Source: Ministry of Transport of China (2018). 
are all located in the Yangtze River Basin, which shows that the "Golden Waterway" of the Yangtze River is well-deserved. Jiangsu Province's seaport transportation is relatively backward, but relying on the Yangtze River golden waterway, it has made a splash in the inland water transportation, occupying 6 seats in the top 10 list, and even the monopoly of the top four, can be described as a huge advantage. Among them, Suzhou Port has been handling more than 600 million tons. This number is only behind Ningbo-Zhoushan Port and Shanghai Port. The development of inland water ports in the central region seems to be backward. Wuhu Port and Yueyang Port are ranked lower, while Wuhan Port and Jiujiang Port are not among the top 10.

Figure 6 shows the relationship between the number of berths and the freight volume in the top 10 inland water ports.

Obviously, although the freight volume of Chongqing is relatively large, its productivity, calculated by the freight volume per berth, is relatively low. In sharp contrast, Suzhou Port, which handles the most freight volume with fewer berths, is the most productive. Other ports are in Quadrant III, indicating that their productivity is normal. Other aspects of port infrastructure are shown in Table 10.

\subsubsection{Constrains and Challenges}

In China, transporting goods by water presents some challenges. The current law

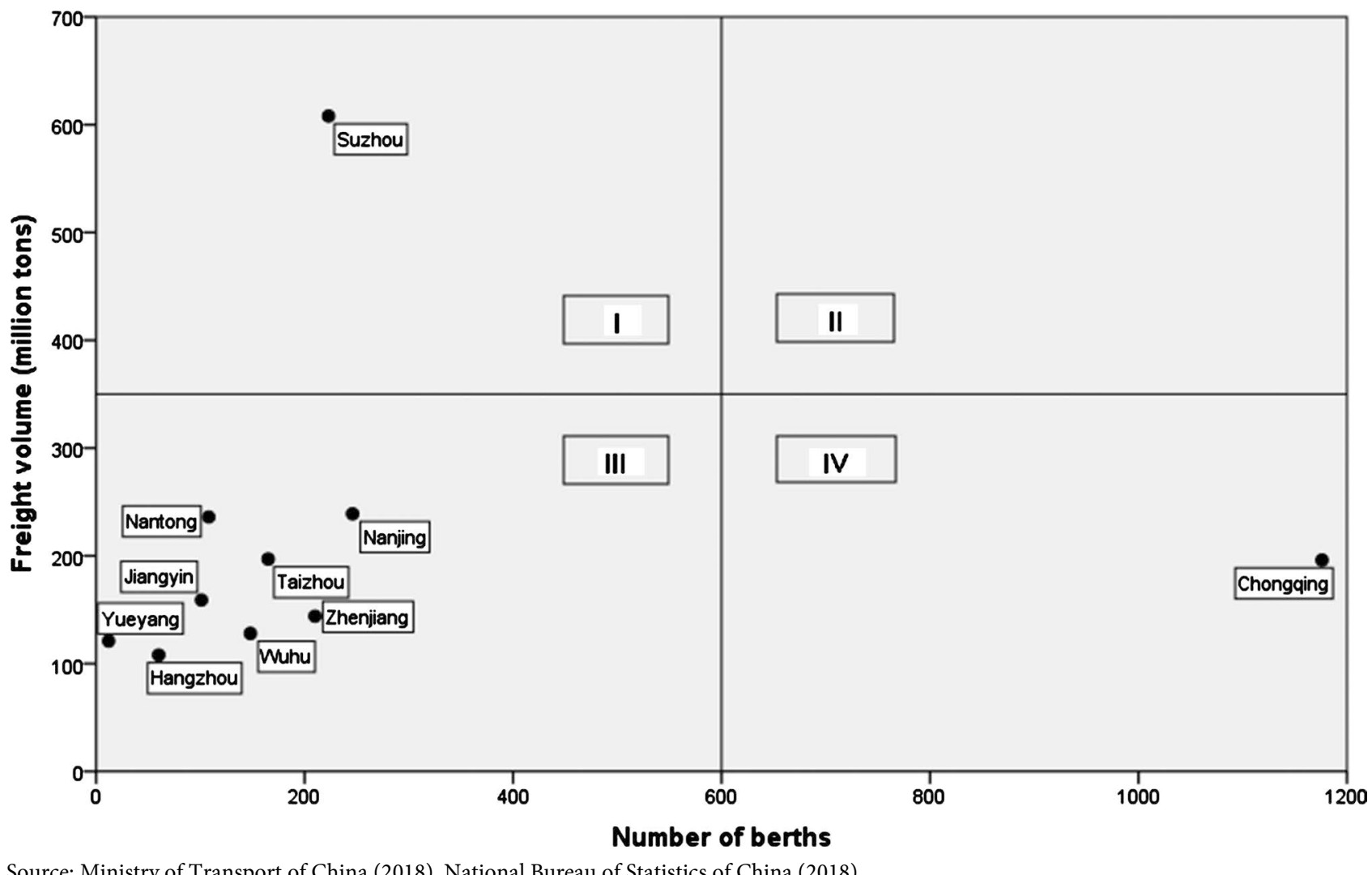

Source: Ministry of Transport of China (2018), National Bureau of Statistics of China (2018).

Figure 6. Productivity of top 10 inland water ports. 
Table 10. Port infrastructure at top 10 inland water ports.

\begin{tabular}{cccc}
\hline Ports & Number berths & $\begin{array}{c}\text { Number of berths for } \\
10,000 \text {-ton ships }\end{array}$ & Length of quays (m) \\
\hline Suzhou & 223 & 107 & NA \\
Nanjing & 246 & 61 & 30,359 \\
Nantong & 108 & 53 & 18,774 \\
Taizhou & 165 & 56 & 20,849 \\
Chongqing & 1176 & NA & 92,013 \\
Jiangyin & 101 & 31 & 14,756 \\
Zhenjiang & 210 & 45 & 22,497 \\
Wuhu & 148 & 13 & 14,808 \\
Yueyang & 12 & NA & NA \\
Hangzhou & 60 & NA & NA \\
Top 10 inland water ports & 2449 & NA & NA \\
All inland water ports & 13,616 & 423 & 902,835
\end{tabular}

Note: NA=not available. Source: National Bureau of Statistics of China (2018)

is generally not comprehensive and the market mechanism is underdeveloped. Many ships and the technology used are very old. Even in large ports like Tianjin Port, Qingdao Port, Shanghai Port and Shenzhen Port, which are at the leading level in China, there is still a big gap between world's advanced ports such as Rotterdam Port, Antwerp Port and Singapore Port. China's ports in relatively high level is only equivalent to the developed countries' in the 1980s. Despite the significant increase in the number of TEUs processed, these ports are still unable to handle large volumes easily because the port infrastructure is below international standards. For example, pavement loading typically allows for the stacking of up to three containers, which is half the average number in more developed ports like Hong Kong Port.

When comparing the data of the Ministry of Transport of China with the data of the US Department of Transportation, we can see that the number of deep water berths in China only accounts for $16.4 \%$ of which in the US, some other indicators are no more than one-third [23]. Despite the global trend of using large container ships, many Chinese ports cannot accommodate such vessels. Therefore, it is important to develop and implement plans to alleviate congestion associated with such high volumes and to cater to large vessels. It can be seen that the large-scale and specialized deep-water berths are insufficient, the mileage of deep-water navigation channels is not enough, the shortage of automation equipment and the low standardization of logistics facilities and equipment have become the bottleneck restricting the development of China's water transport. Traditional Chinese management styles and lack of expertise have created additional barriers.

China has also begun to deal with more commodities containing dangerous 
ingredients. In the past five years, the total amount of dangerous goods transported by waterways in China has increased by nearly $10 \%$ every year [24]. So far, China does not have enough infrastructure and expertise to handle these materials. Security measures are still inadequate, workers are inexperienced, and even shippers may not be able to fully understand the materials they deliver.

At present, the collection and distribution of ports is still dominated by highway. Railway-inland waterway and railway-sea combined transport development is slow. The proportion of railway collection and distribution in ports is only $2 \%$ [23], which is far below the collection and distribution ratio of $10 \%-30 \%$ of international ports.

\subsubsection{Future Developments}

The Government attaches great importance to the inland waterway in the planning of future water transport. For example, in the " $13^{\text {th }}$ Five-Year Plan", the Government plans to build another 320 berths for 10,000-ton ships and increase and improve 4500 kilometers of inland waterways. This will increase the direct freight volume of the Yangtze River trunk line by 300 million tons, and the international transshipment of coastal port containers will increase by 4.5 million TEU [25].

At the end of 2018, the 6-meter water depth channel improvement project from Wuhan to Anqing (Anhui) will start soon and will be done in 2020. At the end of 2019, the second phase of the 12.5-meter deep-water channel of the Yangtze River in Nanjing and its downstream will be completed. In this way, the 10,000-ton ship can reach Wuhan to transport goods all the year round, while the downstream area of Nanjing Port will be able to take 100,000-ton ships [26]. The advantage is that there is no need for ships to unload and turn to sea-going ships but directly reach the sea from inland water. Once the direct access to the rivers and seas is achieved, the Yangtze River's strong navigation capacity will be greatly enhanced, becoming a true golden waterway. Before the end of 2020, regular liners will shuttle between major ports such as Chongqing, Yichang, Wuhan and Nanjing and Shanghai Port. At the end of 2019, the scale and routes of the Yangtze River trunk line linking Shanghai Port and Ningbo-Zhoushan Port will expanded. Similarly, the main upgrade of the Beijing-Hangzhou Grand Canal will be completed in 2019.

In terms of ocean transport, the Ministry of Transport formulated a long-term plan for the development of water transport from 2001-2040. Basically, these plans are to develop the Shanghai International Shipping Center (SISC) as well as major ports in Shanghai, Ningbo, Tianjin, Dalian and Shenzhen, build more deep-water berths, and establish a water transport network covering the whole country [3]. For example, with the help of the Government's RMB 500 billion financial allocation for ports, by the end of 2020, the freight volume of Ningbo-Zhoushan Port will strive to reach 1 billion tons, and the container throughput will reach more than 26 million TEUs [27]. As an important province in the 
Bohai Bay, Hebei Province will allocate 40 billion yuan for the construction and upgrading of the port during the " $13^{\text {th }}$ Five-Year Plan" period [28]. With the implementation of the "Belt and Road" strategy, these seaports will become modern international-level port-oriented industrial clusters that open up to international ports for interactive cooperation and smooth access to maritime trade.

\subsection{Air Transport}

Civil aviation belongs to the jurisdiction of the Civil Aviation Administration of China (CAAC). The CAAC directly controlled China Southern Airlines, China Eastern Airlines and Air China, while other airlines were controlled by local governments or state-owned enterprises before [3]. Now, each airline is a joint-stock company funded by different companies and government. The statistics provided in this section include data on the registration of domestic enterprises engaged in civil aviation, excluding data from foreign companies.

\subsubsection{Current Developments}

By 2016, China had 216 airports, 5046 aircrafts and 2950 transport aircrafts, flying 3794 aviation routes, of which 739 are international routes, 3055 domestic routes and 109 regional routes (routes from China to Hong Kong and Macau). Total length of routes reached 6.35 million $\mathrm{kms}$ (see Table 11). Since 1997, the route to Hong Kong has been reclassified as a domestic route and the length of the route has been adjusted accordingly. Since 1999, all regional routes, including those to and from Hong Kong, form part of the domestic route.

Although air cargo is negligible relative to other modes of transport (Figure 1 and Figure 3), air freight volume has been steadily increasing (Table 12). In 2016, the annual growth rate of air freight volume reached $8 \%$, creating 6.68 million tons.

Table 11. Civil aviation developments.

\begin{tabular}{|c|c|c|c|c|}
\hline Year & 1980 & 1992 & 2004 & 2016 \\
\hline Total number of civil aviation routes & 181 & 563 & 1279 & 3794 \\
\hline Number of international routes & 18 & 58 & 244 & 739 \\
\hline Number of domestic routes & 159 & 492 & 1035 & 3055 \\
\hline Number of regional routes & 4 & 13 & 45 & 109 \\
\hline Total length of routes (million $\mathrm{km}$ ) & 0.20 & 0.84 & 2.05 & 6.35 \\
\hline Length of international routes (million $\mathrm{km}$ ) & 0.08 & 0.30 & 0.89 & 2.83 \\
\hline Length of domestic routes (million $\mathrm{km}$ ) & 0.11 & 0.52 & 1.16 & 3.52 \\
\hline Length of regional routes (million $\mathrm{km}$ ) & 0.00 & 0.02 & 0.06 & 0.17 \\
\hline Number of civil airports & NA & 98 & 133 & 216 \\
\hline Number of civil aircrafts & NA & 602 & 1245 & 5046 \\
\hline Number of transport aircrafts & NA & 315 & 754 & 2950 \\
\hline
\end{tabular}

Note: $1 . \mathrm{NA}=$ not available; 2 . number of airports and aircraft for 1985 to 1990 include only those under direct control of the CAAC. After 1990, they include airport and aircrafts owned by all enterprises of civil aviation. Source: National Bureau of Statistics of China (2018). 
During the same period (1996-2016), the total freight turnover of the airport increased by 7.9 times to 22.2 billion.

Since there is no single airport freight turnover, the top ten airports will be determined based on the freight volume (Table 13). Among them, Shanghai Pudong Airport, Beijing Capital Airport and Guangzhou Baiyun Airport ranked $3^{\text {rd }}, 15^{\text {th }}$ and $18^{\text {th }}$ respectively among the world's top 20 cargo airports in 2017 [29]. These airports have received attention as they are more likely to become logistics hubs.

\subsubsection{Constrains and Challenges}

The direct management of route allocation, airfare and aircraft purchases undermines the primary role of the CAAC as an industry regulator. However, the

Table 12. Civil aviation freight volume and freight ton-kms.

\begin{tabular}{ccccccc}
\hline Year & 1996 & 2000 & 2004 & 2008 & 2012 & 2016 \\
\hline Total freight volume (million tons) & 1.15 & 1.97 & 2.77 & 4.08 & 5.45 & 6.68 \\
Domestic routes (million tons) & 0.25 & 0.49 & 0.70 & 1.19 & 1.57 & 1.93 \\
Reginal routes (million tons) & 0.82 & 1.47 & 2.06 & 2.88 & 3.89 & 4.75 \\
International routes (million tons) & 0.08 & 0.13 & 0.17 & 0.16 & 0.21 & 0.22 \\
Total freight ton-kms (million) & 2493 & 5027 & 7180 & 11,960 & 16,389 & 22,245 \\
Domestic routes (million) & 1242 & 2916 & 4188 & 7737 & 10,645 & 15,034 \\
$\quad$ Reginal routes (million) & 1142 & 2111 & 2992 & 4223 & 5744 & 7211 \\
International routes (million) & 109 & 195 & 260 & 241 & 271 & 275 \\
\hline
\end{tabular}

Source: National Bureau of Statistics of China (2018).

Table 13. Top 10 airports (2017).

\begin{tabular}{cccc}
\hline Airport & Administrative region & $\begin{array}{c}\text { Freight volume } \\
\text { (million tons) }\end{array}$ & $\begin{array}{c}\text { Per cent of total freight } \\
\text { volume (per cent) }\end{array}$ \\
\hline Shanghai Pudong & Shanghai municipality & 3.82 & 23.70 \\
Beijing Capital & Beijing municipality & 2.03 & 12.59 \\
Guangzhou Baiyun & Guangdong province & 1.78 & 11.04 \\
Shenzhen Baoan & Guangdong province & 1.16 & 7.20 \\
Chengdu Shuangliu & Sichuan province & 0.64 & 3.97 \\
Hangzhou Xiaoshan & Zhejiang province & 0.59 & 3.10 \\
Zhengzhou Xinzheng & Henan province & 0.50 & 2.61 \\
Kunming Changshui & Yunnan province & 0.42 & 2.54 \\
Shanghai Hongqiao & Shanghai municipality & 0.41 & 2.30 \\
Nanjing Lukou & Jiangsu province & 0.37 & 72.70 \\
Top 10 airports & All airports & 11.72 & 100 \\
\hline
\end{tabular}

Source: CAAC (2018). 
Civil Aviation Authority is expected to abandon control of these airlines and become a regulatory body responsible for future aviation safety and air route approvals. In addition, Chinese policymakers openly acknowledge that China lags behind developed countries in terms of the number, size, service and management standards of airports [30]. Due to the limited number of airports, the network coverage is sparse and air transportation services are weak. The United States has 5.98 airports per 10,000 square kilometers, compared with 0.23 in China [13]. The number of aircraft available for freight is limited, and several aircraft are also old, deteriorating due to wear and tear. As of the end of 2015, 102 cargo planes in the domestic civil aviation market were scattered among 7 cargo airlines and 1 passenger and cargo airline, and the largest number was only 32 [31]. The runway quality at many airports is also poor. Due to the lack of a national aviation logistics information platform, air transportation processes and procedures are neither advanced nor adequate.

The lack of regulations brings additional problems. China's aviation logistics industry still has no perfect industrial guidance policies and overall development plans at the national level, resulting in chaotic management of the aviation logistics market. Many air cargo agencies lacking legal authorization disrupt market order, reduce industry integrity and infringe on the interests of legitimate agencies.

\subsubsection{Future Developments}

The Chinese Government plans to invest RMB 650 billion during the "13th Five-Year Plan" to improve aviation services and expand the airport network [32]. Therefore, the construction of the new transport airport will bring the total to 260 by 2020, an increasing of 53 compared to 2015 [33]. Despite the difficulties, China will endeavor to build a hub and spoke network, with national hubs located in Beijing, Guangzhou and Shanghai. The annual throughput growth rates of Guangdong Baiyun Airport and Shanghai Pudong Airport are over 7\% and $11 \%$ respectively. Beijing Daxing Airport is China's most advanced international airport. It will be completed in 2019 and can handle 2 million tons of cargo per year [34].

In order to further expand the channels for investment and financing of civil aviation and fully mobilize the enthusiasm of civil investment in civil aviation, the CAAC and the National Development and Reform Commission jointly organize civil aviation to encourage private investment. In 2018, 28 private investment projects with a total investment of RMB 110 billion have been identified. These projects cover civil aviation traditional areas such as transportation airport construction, general airport construction, freight logistics, aircraft maintenance, aviation rescue, as well as UAV logistics distribution, UAV flight verification, navigation technology, airborne data communication, etc. [35]. One of the most eye-catching projects is the construction of Ezhou Airport, namely the Shunfeng (SF) International Airport in Hubei Province. The total investment of the airport is 37.26 billion yuan, which is jointly funded by the Hubei Provincial Government and the SF Express Group. It is planned to be completed in 
2021. The airport will serve as an international logistics hub and is expected to support 2.5 million tons of cargo by 2025 and 1.5 million passengers and 3.3 million tons of cargo by 2030 [36].

Due to the full awareness of growth opportunities in the freight sector, many Chinese airports are embarking on the construction of independent freight facilities to improve cargo handling capacity. One of the airports is Ezhou Airport, which is an important regional cargo hub built with Memphis as the benchmark. To attract more business, Ezhou Airport will provide low taxes, fast customs clearance, low cost freight housing and low landing fees.

On the other hand, the airport cooperates closely with each other through enhanced cooperation and mergers. For example, Beijing Capital International Airport merged with Daxing International Airport in 2019, creating greater synergy. At the same time, Shanghai Pudong Airport and Hongqiao Airport are under the responsibility of Shanghai Airport Group, thus rationalizing their routes. Similarly, Guangzhou Baiyun Airport and Shenzhen Airport are keen to cooperate with each other.

\section{Customs}

\subsection{Current Developments}

Customs formalities are regulated and standardized by the General Administration of Customs (GAC). In 2016, the national tariffs reached 260.3 billion yuan and have increased substantially after China joint to WTO in 2001 (Figure 7).

Specific matters concerning entry and exit are handled by customs at each local or regional level. The process begins with the receiver or shipper's statement and submits the import and export license and related documents to the customs for examination. These documents include the bills of lading, invoices, shipping lists, import or export licensing documents, inspection certificates issued by the GAC for Quality Supervision, Inspection and Quarantine or its local bureau,

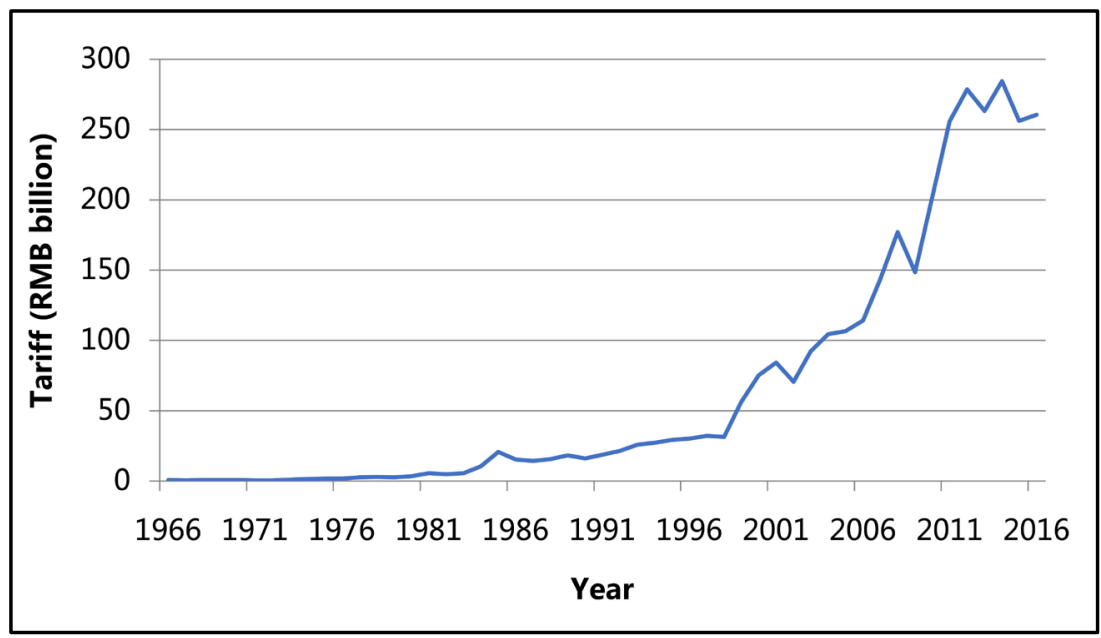

Source: National Bureau of Statistics of China (2018).

Figure 7. China tariff developments (1966-2016). 
insurance policies, and customs declaration forms. Other types of items may require additional documentation. The customs can also conduct a physical examination of imported goods. After the customs evaluates the statement, it will determine the amount of the tariff to be imposed.

Tariffs are classified according to the trade name and coding system. According to the 8549 tariff headings, the import tariff rate averaged $7.5 \%$ [37]. The average import tariff rate is much lower than the previous $16.4 \%$ in 2000 [3], proving that China has earnestly fulfilled its commitment to reduce tariffs when joined WTO. Take the recent tariff reduction as an example, since July 1, 2018, China has reduced the MFN tariff rate for auto vehicles from 25\% and 20\% to $15 \%$, and reduced the MFN tariff rate for auto parts from a maximum of $25 \%$ to $6 \%$, and reduced the import tariffs of some consumer goods to a larger extent, involving 1449 tariff items, the MFN average tariff rate dropped from $15.7 \%$ to $6.9 \%$, with an average drop of $55.9 \%$ [38].

Although importers/exporters must pay the corresponding tariffs for most products, some goods are eligible for tax reduction or tax exemption, but other commodities face restrictions and bans (Table 14).

\subsection{Constrains and Challenges}

Many companies face difficulties in customs clearance because the labyrinth of

Table 14. Products granted tax reduction/exemption, restricted or prohibited.

\section{Products}

\section{Imports}

Granted tariff reduction or exemption

One-ticket cargo with a customs duty of less than RMB 50; non-commercial advertising products and samples; foreign government, international organizations donated materials for free; goods lost or damaged before customs clearance; fuel, materials and food supplies necessary for the loading of inbound and outbound vehicles

Restricted

Radio transceiver, communication security machine; cigarette, wine; endangered and precious animals, plants (both including specimens) and their seeds and propagation materials; national currency

Prohibited

Various weapons, simulated weapons, ammunition and explosives; forged currency and forged securities; prints, films, photographs, records, films, audio tapes, video tapes, laser discs, computer storage media and other items that are harmful to China's politics, economy, culture and morals; various potent poisons; opium, morphine, heroin, marijuana and other narcotics and psychotropic substances that are addictive; animals, plants and their products with dangerous germs, pests and other harmful organisms; food, medicines or other items that are harmful to human and animal health, from infected areas and other diseases that can spread diseases

\section{Exports}

Granted tariff reduction or exemption Same as imports

Restricted

Prohibited
Precious metals such as gold and silver and their products; national currency; foreign currency and its securities; radio transceiver, communication security machine; precious Chinese herbal medicine; general artifacts

All items included in the prohibited entry range; manuscripts, prints, films, photographs, records, films, audiotapes, videotapes, laser discs, computer storage media and other items that involve nation secrets; precious cultural relics and other text carriers that are prohibited from leaving the country; endangered and precious animals, plants (both including specimens) and their seeds and propagation materials

Source: GAC (2018). 
rules and regulations is often unclear. If we use 1 to 7 points to represent customs efficiency from low to high, China Customs scored 4.6 points in 2017. Although this figure is higher than 4.2 points in 2007, it is far lower than Singapore's 6.3 points, Hong Kong's 6.0 points and the United States' 5.6 points [39]. Customs officials can make arbitrary decisions due to the lack of a set of fixed guidelines and procedures during the dispute. An official can easily claim that he cannot verify the statement, and conduct investigation, which may eventually result in the confiscation of the goods, fines or even legal proceedings. Although the GAC strives to standardize customs regulations throughout China, some officials continue to make arbitrary decisions on various matters, such as the category of certain commodities [40].

Damage to the goods during customs clearance is also very serious. Many fragile items are often damaged by violent out-of-the-box inspections. Similarly, goods with high freshness requirements, such as fruits, meat, aquatic products and medicines, often deteriorate or lose their effectiveness due to lengthy and complicated customs clearance procedures. Customs clearance time can range from two days to two months which is much higher than the world average level of 7 days [41]. If the customs decide to check each shipment, customs clearance will take longer. If the customs find that the import and export goods are unfamiliar, the customs clearance time will be greatly extended. Then, the customs may take weeks or even months to determine the appropriate product classification category. Such unstable customs clearance time makes it difficult to provide a satisfactory estimate of the arrival and departure dates of the goods.

\subsection{Future Developments}

"Reducing tariffs and promoting openness" has always been the subject of frequent research in the State Council executive meeting. In September 2018, the Government decided to reduce the rate of 1585 import tariff headings of industrial products from 1 Nov, 2018. Among them, the Government reduced the average import tariff rate (AITR) of mechanical machinery, instrumentation and other mechanical and electrical equipment with a large demand in the domestic market from $12.2 \%$ to $8.8 \%$, and the AITR for textiles, building materials and other commodities decreased from $11.5 \%$ to $8.4 \%$, and the AITR of some resource products and primary processed products such as paper products fell from $6.6 \%$ to $5.4 \%$, and the AITR for similar goods was reduced [37].

The GAC is also working hard to promote cross-border trade facilitation. In terms of the reduction of documents, there are 86 kinds of supervision certificates for the import and export links at the current stage. The GAC plans to cancel 8 kinds, 12 kinds of mergers, and 18 types of exit port inspections before 1 November, 2018, and the total number will be reduced to 48. In terms of efficiency, the GAC will ensure that the overall customs clearance time for imports and exports will be reduced by one-third from 2017 by the end of 2018, with imports from 97.39 hours to 65 hours and exports from 12.29 hours to 8.2 hours. By the end of 2021, the overall customs clearance time for imports was reduced 
by half to 30 hours in 2017; the overall customs clearance time for exports was reduced by half to 6.15 hours. In addition, the General Administration of Customs will further improve the intelligence and informatization level of port logistics. By the end of 2018, the main business application rate of "single window" will be increased to $80 \%$, and $100 \%$ by the end of 2020 [42].

\section{Warehousing}

\subsection{Current Developments}

In recent years, the development of China's warehousing industry has achieved remarkable results. By the end of 2016, there were about 29,000 warehouse enterprises in China, and about 129,000 people employed in the industry (National Bureau of Statistics of China, 2018). The fixed assets investment in the warehousing industry was RMB 698 billion, the newly added fixed assets were RMB 415 billion, and the total assets of the industry was RMB 2.07 trillion. Due to the investment in the industry turning to the function of improving the end node construction, informatization, and intelligence (cloud warehousing, big data, Internet of Things) and the investment in the warehousing industry has increased substantially for ten consecutive years which makes the storage facilities have become increasingly saturated, the total assets of the warehousing industry declined for the first time, down 9.4\% year-on-year [43].

Since the beginning of the $21^{\text {st }}$ century, the warehouse area has expanded rapidly. As of the end of 2016, China's commercial general warehouse area was about 998 million square meters, up 4.5\% year-on-year; the total cold storage volume was about 120,000 cubic meters, up $12.5 \%$ year-on-year (National Bureau of Statistics of China, 2018).

\subsection{Constrains and Challenges}

China's high-quality warehouse market has traditionally been dominated by single-storey warehouses, which are cheaper to construct than multi-storey warehouses and tend to be more tenant. But rising land prices have made single-storey projects less feasible. In addition, the land is owned by the nation, and there is no department in China to uniformly manage the distribution of warehouse land, which leads to difficulties in the development of the quantity and quality of the warehouse. Most warehouses can only be used for general storage purposes.

Complex shelves are rare, so the goods are usually stacked on the floor, which is an inefficient use of space and can cause damage to the carton. Similarly, due to the lack of automated high-end warehousing facilities, most picking and order picking is still done manually. So that in the foreseeable short to medium term, it is more economical to hire more labor than automated warehouse activities. Until the labor and equipment costs are close to equilibrium, the propensity for warehouse automation is still small. In addition to heavy initial capital expenditures, automation of warehouse activities will also result in additional costs for 
trainers to effectively use new technologies.

\subsection{Future Developments}

In order to attract more investment and promote the logistics industry, more complex warehouses are being built. For example, Beijing will build many logistics centers (LCs) during the " $13^{\text {th }}$ Five-Year Plan" period (Table 15). Domestic and foreign investors are now building more warehouses across the country, either collectively or individually. With the liberalization of the logistics industry, more and more foreign companies are building specialized warehouses.

\section{Conclusions}

This paper emphasizes the reality of logistics developments in China. Transportation, customs and warehousing continue to pose challenges. Improvements in China's crowded transportation network are already underway. A smooth and efficient distribution network has begun to emerge. The lack of a physical high-tech warehouse structure and a computerized customs system is indeed a logistics barrier that plagues any emerging economy, as does China. However, the bigger challenge is to develop a skilled and knowledgeable workforce that knows how to take advantage of emerging technologies, and that policymakers have the quick political will to develop appropriate laws and regulations to promote truly seamless information flow across provinces and municipalities.

Current distribution system deficiencies undermine the ability of multinational companies to take full advantage of the Chinese market potential. With the right push and predictable improvements to transportation systems, multinational companies and LSPs may be more likely to take advantage of this huge market faster than expected. Given China's current attitude toward the WTO, the potential for logistics growth is enormous. Provincial governments also need to reform their logistics infrastructure more urgently to match other countries. International aid agencies such as the World Bank, the Asian Development Bank

Table 15. LC projects in the $13^{\text {th }}$ FYP.

\begin{tabular}{ccc} 
Project & Area (square kms) & Main function \\
\hline $\begin{array}{c}\text { Beijing Airport LC } \\
\text { Fengtai International } \\
\text { Commodity LC }\end{array}$ & 1.55 & $\begin{array}{c}\text { Import and export logistics and } \\
\text { warehousing of Beijing Capital } \\
\text { International Airport }\end{array}$ \\
$\begin{array}{c}\text { Tongzhou Smart LC } \\
\text { International commodity trading, storage, } \\
\text { distribution }\end{array}$ & $\begin{array}{c}\text { Cold chain logistics, e-commerce logistics, } \\
\text { food circulation }\end{array}$ \\
Pinggu Port LC & 4 & $\begin{array}{c}\text { Car parallel import, cross-border } \\
\text { e-commerce, aviation spare parts bonded } \\
\text { whijingshan Freight Yard }\end{array}$ \\
\hline
\end{tabular}

Source: Beijing $13^{\text {th }}$ Five-Year Logistics Development Plan. 
and the Asian Infrastructure Investment Bank can do more to help develop and fund critical infrastructure projects. The approval process for these projects should also be expedited.

This paper provides any firms wishing to enter the Chinese market, either multinational companies or LSPs with an excellent opportunity to be better prepared for the logistical challenges in moving goods either physically or electronically through the compendium of information. Understanding the state of the world's largest market for logistics can help company managers or decision makers accurately redefine their supply chain strategies in specific regions of China and determine strengths and weaknesses each region's logistics.

\section{Conflicts of Interest}

The authors declare no conflicts of interest regarding the publication of this paper.

\section{References}

[1] Maddison, A. (2003) The World Economy: Historical Statistics. Organisation for Economic Co-Operation and Development, Paris. https://doi.org/10.1787/9789264104143-en

[2] Jiang, B. and Prater, E. (2002) Distribution and Logistics Development in China: The Revolution Has Begun. International Journal of Physical Distribution \& Logistics Management, 32, 783-798. https://doi.org/10.1108/09600030210452459

[3] Goh, M. and Ling, C. (2003) Logistics Development in China. International Journal of Physical Distribution \& Logistics Management, 33, 886-917. https://doi.org/10.1108/09600030310508708

[4] Hong, J. and Liu, B. (2007) Logistics Development in China: A Provider Perspective. Transportation Journal, 46, 55-65.

[5] Liu, X. (2014) China-Based Logistics Research: A Review of the Literature and Implications. International Journal of Physical Distribution \& Logistics Management, 44, 392-411. https://doi.org/10.1108/IJPDLM-08-2012-0225

[6] Ding, J. (2018) The Development of China's Logistics Industry during the Past 40 Years of Reform and Opening-Up and the Outlook of That. China Business and Market, 4, 3-17.

[7] Wang, W. and He, M. (2017) The Development Track, Stage Characteristics and Future Prospect of China's Logistics Industry Since the Reform and Opening-Up. Reform, 11, 23-34.

[8] China, N.B. (2018) China's 2017 National Economic and Social Development Statistics Bulletin.

[9] China, M.T. (2018) 2017 Road Cargo Transportation Volume Data Report.

[10] Lan, L. (2016) National Highway "Twelfth Five-Year" Review and "Thirteenth Five-Year Plan” Outlook. Transport Construction \& Management, Z1, 68-77.

[11] Council, S. (2017) “ $13^{\text {th }}$ Five-Year Plan" Modern Comprehensive Transportation System Development Plan. Beijing.

[12] National Development and Reform Commission, M. o. T., China Railway Corporation (2017) " $13^{\text {th }}$ Five-Year" Railway Container Multimodal Transport Development Plan. Beijing. 
[13] Zhang, J. (2018) Discussion on the Development of Car-Free Carriers in the Logistics Industry. Market Modernization, 11, 15-17.

[14] Daily, B. (2018) Train for the Benefit of the People of the New Era. http://news.cnr.cn/native/gd/20180715/t20180715_524301002.shtml

[15] Transport, C.R.C. (2018) The Number of CEIBS Trains Exceeded 10,000. http://www.crct.com/

[16] He, Y. (2017) Railway Capacity Is a Bottleneck. China Coal News, 7.

[17] Council, S. (2016) White Paper on China's Transportation Development. http://www.xinhuanet.com/politics/2016-12/29/c_1120210887.htm

[18] Bank, W. (2014) World Bank Loan of 600 Million US Dollars to Boost China's Railway, Public Transport Construction and Gas Utilization. http://www.shihang.org/zh/news/press-release/2014/03/28/world-bank-600-million -railway-transport-gas-utilization-china

[19] Wikipedia (2018) List of Busiest Container Ports. https://en.wikipedia.org/wiki/List_of_busiest_container_ports

[20] Hu, F. (2009) The Adaptability between Waterway Navigation Capabilities and Logistics Demands of Yangtze River. Wuhan University of Technology, Wuhan.

[21] Zhu, W. (2003) The Research about the Development of the Pearl River's Waterway Transportation. Wuhan University of Technology, Wuhan.

[22] China M. o. T. o. (2017) 2016 Statistical Bulletin of the Development of the Transportation Industry. Finance \& Accounting for Communications, 5, 92-97.

[23] Network, C.W.T. (2016) Analysis on the Problems Existing in China's Port Logistics. http://www.zgsyb.com/html/content/2016-05/30/content_499797.shtml

[24] Han, Y. (2017) Safety Evaluation and Safety Management Countermeasures of Dangerous Goods Maritime Transportation in China-Based on the Perspective of Vulnerability-Capacity. China Water Transport, 17, 46-49.

[25] China M. o. T. o. (2016) Water Transport “13th Five-Year” Development Plan. Beijing.

[26] Ding, J. and Nian, K. (2018) Inland Waterway and Port Planning Will Be Adjusted. 21st Century Business Herald. http://www.21jingji.com/2018/9-12/wNMDEzNzlfMTQ0ODgwNA.html

[27] Government Z. P. P. s. (2016) The 13th Five-Year Plan for the Development of Marine Ports in Zhejiang Province. http://www.zj.gov.cn/art/2016/5/3/art_1582439_26045312.html

[28] Goverment H. P. P. s. (2016) The 13th Five-Year Plan for the Development of Comprehensive Transportation System in Hebei Province. https://www.sohu.com/a/153367540_772491

[29] Harris, D. (2018) Top 20 Cargo Airports in 2017. https://cargofacts.com/top-20-cargo-airports-in-2017/

[30] Wang, Z. and Fang, R. (2017) On the Supply-Side Reform to Promote the International Development of China's Civil Aviation Industry. CAAC News, 7.

[31] Wei, R. and Zhang, L. (2017) The Development Situation and Trend of Aviation Logistics of China. Prices Monthly, No. 4, 82-86.

[32] Ding, J. and Wang, P. (2017) “13th Five-Year" Transportation Investment 15 Trillion. 21st Century Business Herald, 1.

[33] CAAC, Commission N. D. a. R. and Transport M. o. (2016) China's Civil Aviation Development 13th Five-Year Plan. Beijing. 
[34] Wu, D. (2018) The Name of Beijing New Airport Is Determined as "Beijing Daxing International Airport". CAAC News, 1.

[35] Bai, W. (2018) The First Batch of Civil Aviation Field Encourages the Publication of Private Investment Projects.

http://www.gov.cn/xinwen/2018-08/23/content_5315940.htm

[36] Aviation C. f. (2018) Ezhou Airport.

https://centreforaviation.com/data/profiles/newairports/ezhou-airporthubei-interna tional-logistics-hub

[37] Liu, H. (2018) China's Total Tariff Level Will Drop to 7.5\%. Xinmin Evening News. http://xmwb.xinmin.cn/lab/html/2018-09/27/content_10_1.htm

[38] Qiu, H. (2018) China's Commitment to WTO Accession Is Unambiguous. People's Daily.

[39] Bank, W. (2018) Customs Burden. https://data.worldbank.org.cn/indicator/IQ.WEF.CUST.XQ?.year_high_desc=true

[40] E, L. and Liu, Z. (2014) Cross-Border e-Commerce Customs Clearance Research. Intertrade, No. 9, 32-34.

[41] Bank, W. (2018) The Average Time for Customs to Handle Import and Export Procedures. https://data.worldbank.org.cn/indicator/IC.CUS.DURS.EX

[42] Liu, H. and Ma, R. (2018) The General Administration of Customs Pushes a Number of Initiatives to Promote Cross-Border Trade Facilitation. http://www.xinhuanet.com//2018-09/27/c_1123491955.htm

[43] Jiang, P. (2018) Analysis on the Status Quo and Investment Prospect of China's Warehousing Industry in 2018.

https://www.qianzhan.com/analyst/detail/220/180329-6b87f6fb.html 